\title{
ARAŞTIRMA / RESEARCH \\ Üniversite öğrencilerinde uykusuzluk, yorgunluk ve ağrıda kullanılan tamamlayıcı ve alternatif yöntemler
}

Complementary and alternative methods used in the case of insomnia fatigue and pain among University students

\author{
Kevser Sevgi Ünal110, Ebru Gözüyeşi1 ${ }^{1}$ iD, Edanur Tar1 ${ }^{\text {iD }}$ \\ ${ }^{1}$ Korkut Ata Universitesi, Osmaniye Sağlık Yüksekokulu, Osmaniye, Turkey
}

\section{Cukurova Medical Journal 2019;44(2):602-611}

\begin{abstract}
Purpose: The aim of this study is to investigate the use of alternative methods in pain, insomnia and fatigue of foreign students.

Materials and Methods: This research was carried out with 100 international students studying at a university in Turkey. Socio - demographic characteristics of the students prepared by the researchers in accordance with the literature information (gender, age, thickness etc.) 30 question data collection form which evaluates some of the features associated with the use of taste. Percent, frequency and mean tests were used in the evaluation of the data.

Results: The average age of the foreign students participating in the study is $21.52 .43 \%$ of the students are female and $57 \%$ are male students. $79 \%$ of the students are Syrian, 15\% Afghans, 6\% Turkmen nationality. When $49 \%$ of foreign students encountered sleep problems, 34\% applied for Complementary Alternative Treatment (TAT) in the case of tiredness and $13 \%$ applied for pain management. $45 \%$ of the students in pain management $27 \%$ in fatigue, $21 \%$ in sleep problem when faced with the pharmacological methods were found to apply.

Conclusion: In this study, it was determined that the students applied to the methods of Complementary Alternative Treatment when they encountered the most sleep problem and preferred the pharmacological methods in pain management.
\end{abstract}

Keywords: TAT methods, pain, sleep, fatigue, university students

\section{Öz}

Amaç: Bu araștırmada yabancı uyruklu öğrencilerin ağnı, uykusuzluk ve yorgunlukta tamamlayıc1, alternatif yöntemler kullanma durumlarının incelenmesi amaçlanmıştır.

Gereç ve Yöntem: Tanımlayıcı ve ilișki arayıcı tipte yapılan bu araştırma Türkiye'de bir üniversitede öğrenim gören 100 uluslararası öğrenci ile yürütülmüștür. Araştırmacılar tarafından literatür bilgileri doğrultusunda hazırlanan öğrencilerin sosyo-demografik özellikleri (cinsiyet, yaş, kalınan yer v.s) ve Tamamlayıcı ve Alternatif Tedaviler (TAT) kullanımı ile ilișkili bazı özellikleri değerlendiren 30 soruluk veri toplama formudur. Verilerin değerlendirilmesinde yüzde, frekans ve ortalama testleri kullanılmıștır.

Bulgular: Araştırmaya katılan yabancı uyruklu öğrencilerin yaş ortalaması 21.52 'dir. Öğrencilerin $\% 43$ kadın, \%57 si ise erkek öğrencilerden oluşmaktadır. Öğrencilerin \%79'u Suriyeli, \%15'i Afgan, \%6's1 Türkmen uyruklu'dur. Yabancı uyruklu öğrencilerin \%49'u uyku problemi ile karsıllaştıklarında, \%34'ü yorgunluk durumunda, \%13’ü ise ağrı yönetiminde tamamlayıcı alternatif tedavi (TAT) kullanımına başvurdukları belirlenmiștir. Öğrencilerin \%45'i ağr1 yönetiminde, \%27'si yorgunluk'da, \%21'i uyku problemi ile karşılaştıklarında farmakolojik yöntemlere başvurdukları saptanmıştır.

Sonuç: Bu çalışmada öğrencilerin en çok uyku problemi ile karşılaştıklarında TAT yöntemlerine başvurdukları, ağnı yönetiminde ise farmakolojik yöntemleri tercih ettikleri belirlenmiştir.

Anahtar kelimeler: TAT yöntemleri, ağrı, uyku, yorgunluk, üniversite öğrencileri,

Yazışma Adresi/Address for Correspondence: Dr. Kevser Sevgi Ünal, Korkut Ata Universitesi, Osmanive Sağllk Yüksekokulu, Osmaniye, Turkey E-mail: mail:kevser-sevgi@hotmail.com

Geliş tarihi/Received: 19.10.2018 Kabul tarihi/Accepted: 26.11.2018 Çevrimiçi yayın/Published online: 23.03.2019 


\section{GİRİ̧̧}

Alternatif Tıp Merkezi (NCCAM)'nin tanımına göre tamamlayıcı ve alternatif tedaviler (TAT); "modern tıbbın bir parçası sayılmayan fakat sağlık bakım sistemlerinde ve tıbbin farklı alanlarında bulunan uygulama ve ürünler" olarak tanımlanmaktadır ${ }^{1}$. Alternatif tıp çoğunlukla modern tıbbın yerine kullanılan kanıtlanmamış tedavilerden oluşmaktadır. Tamamlayıcı tıp ise temel olarak modern tıbba eşlik eden ya da onu tamamlayan yöntemleri içermektedir². Tamamlayıc1 ve alternatif tedavi tanımları farklı kavramlar olmasına rağmen literatürde birleşerek TAT terimini oluştururlar ${ }^{1}$.

Dünyada ve ülkemizde tamamlayıcı ve alternatif tıp kullanma oranı giderek artış göstermektedir. TAT yöntemlerinin kullanım oranlar1; Amerika'da \%42,1, Avustralya'da \%48,2, Fransa'da \%49,3, Kanada'da $\% 70,4$ iken gelişmekte olan ülkelerden Şili'de \%71, Çin'de \%70, Kolombiya'da \%40 ve Afrika ülkelerinde $\%$ olarak görülmektedir ${ }^{3}$. Türkiye'de TAT kullanımına yönelik çalışmaların az olması, TAT ile ilgili yeterli bilgiye sahip olunmaması ve uygulama yapacak profesyonel kişi sayısının az olmasına bağlı olarak TAT kullanımının yaygınlığı ile ilgili kesin verilere ulaşmak mümkün olmamaktadır ${ }^{4}$. Kav ve arkadaşlar1 $^{5}$ tarafindan, örneklemi kanser hastaları olan, 2001-2007 yıllarında yayınlanmış 14 makale ve 7 çalışma incelenmiş ve TAT kullanım sıklığının \%22.1 ve $\% 84.1$ aralığında olduğu sonucuna ulaşılmıştır. Literatür de çalışmaların temel olarak spesifik bir gruba odaklanıldığı görülmektedir.

Hastalıkların tanı ve tedavi sürecinde yaşanan gelişmelere rağmen sağlık sorunlarına çözüm bulmakta yetersiz kalınmaktadır. Bu aşamada farmakolojik yöntemlerle birlikte TAT kullanımının önemi artmaktadır. Hemşireliğin uygulama alanı ve TAT yöntemlerinin temel felsefesi, bireye holistik yaklaşmaları, sağlığın yükseltilmesi ve hastanın aktif rolde olmasına yöneliktir ${ }^{6}$. Bireylerin inançları, yaşam şekilleri ve kültürel farklılıkları TAT kullanımını önemli ölçüde etkilemektedir ${ }^{7}$. Hemşireler bireylere holistik bakım verirken kültürel farklılıklar ve benzerlikler hakkında bilgi sahibi olmalı ve bireylerin gereksinimlerinin karşılanmasında kültüre duyarlı olmalıdır ${ }^{6}$. Leininger'in kültür bakım çeşitlilik ve evrensellik kuramına göre hemşire farklı kültürlere ait bilgisini artırdıkça hastalara daha iyi bakım verebilecek ve daha iyi tedavi edebilecektir8 ${ }^{8}$. Literatür incelendiğinde bireyler ağrı, uykusuzluk ve yorgunluk durumlarında tat kullanımına sik sik başvurmaktadırlar9 ${ }^{9}$ Erdoğan ve ark. çalışmasında kronik böbrek yetmezliğine sahip bireylerin yorgunluk, ağrı ve uyku bozuklukları başta olmak üzere kramplar, anksiyete, depresyon, kaşıntı gibi semptomlarla baş edebilmek ve yaşam kalitelerini artırmak için akupressure, akupunktur, homeopati, egzersiz, aromaterapi, yoga ve refleksoloji gibi diğer TAT yöntemlerini yaygın olarak kullandıkları belirlenmiştir?

İnsanlar yaşamları boyunca belirli dönemlerde ağn1 yaşamaktadırlar. Ağrısı olan bireylerin uyku düzeni, aile yaşantısı, sosyal yaşantısı, iş verimi ve günlük yaşam aktivitelerini sürdürmesi olumsuz olarak etkilenmektedir ve dolayısıyla yaşam kalitesi düşmektedir. Bireylerin rahatlatılması, komplikasyonların azaltılması ve yaşam kalitesinin artırılması amacıyla ağrı kontrol altına alınmalıdır ${ }^{10}$. Hızlı etki göstermesi, kolay ulaşılabilir ve uygulanabilir olması ağrı yönetiminde farmakolojik tedavinin kullanımını artırmaktadır. Ancak ilaçların maliyetinin yüksek olması, bilinçsiz kullanım ve yan etkiler gibi olumsuzluklarının olması nonfarmakolojik yöntemlerin kullanımını desteklemektedir ${ }^{11}$. Dünyada olduğu gibi ülkemizde de çeşitli sebeplerden kaynaklanan ağrıların tedavisinde non-farmakolojik yöntemler içeren TAT, hemşireler ve bireyler tarafindan yaygın olarak kullanılmaktadır ${ }^{12}$. Bireylerin ağrısının değerlendirilmesi ve önlenmesi nitelikli hemşirelik bakımının bir göstergesi olduğundan hemşireler için ayrı bir önem taşımaktadır. Ağrı kontrolünde sık kullanılan TAT yöntemleri arasında; soğuk-sıcak uygulamalar, egzersiz, pozisyon verme, dinlenme, akupunktur, TENS, masaj ve dokunma; gevşeme, dikkati başka yöne çekme, dua etme, meditasyon, hipnoz, refleksoloji, aromaterapi, müzik terapi vb. yer almaktadır ${ }^{13}$.

Kronik hastalık varlığı ile birlikte bireylerin birçoğu uykusuzluk problemi yaşamaktadırlar. Uykusuzluk, ruh halinde değişikliğe, konsantrasyon ve hafıza problemleri, uzun süreli fiziksel ve zihinsel tükenmeye neden olarak insanın yaşam kalitesini etkilemektedir ${ }^{14}$. Bilişsel davranışların ve zihinsel yeteneklerin azalmasiyla birlikte genel durumun bozulması nedeniyle yaşamın sosyal ve profesyonel yönleri etkilenebilmektedir. Uykusuzluk sorunu yaşayan bireyler hemşireler tarafindan erken tespit edilip gerekli bakım gereksinimleri karşılanırsa uykusuzluk ile ilişkili fizyolojik, psikolojik, sosyal sorunlar önlenebilir. Bireylerin uykusuzluğu tedavi etmek ve uyku problemlerini çözmek için \% 49.2 'sinin bitkisel tedavileri, \%48.2'sinin ise gevşeme terapilerini 
yaygın olarak kullandıkları belirlenmiştir ${ }^{14}$.

NANDA tarafindan bir hemşirelik tanısı olarak kabul edilen ve dinlenmekle geçmeyen, fiziksel ve mental iş kapasitesini azaltan, sürekli bitkinlik duygusu yaşama olarak tanımlanan yorgunluk; bireylerin yaşamları üzerinde önemli etkilere sahiptir ${ }^{15}$. Bireylerin sürekli enerji yoksunluğu yaşadıklarından ve rutin işlerini yapamadıklarından söz etmeleri, fiziksel ve duygusal yakınmalarda bulunmaları, huzursuzluk, konsantrasyon bozukluğu, çevreye karşı ilgisizlik, cinsel güçte azalma, ve kazalara yatkınlık yorgunluk sonucunda gelişebilen durumlardır ${ }^{16}$. Kronik yorgunluk durumu erken tanilanmalı ve olumsuz sonuçları önlemek adına hemen müdahale edilmelidir. Porter arkadaşlarının ${ }^{17}$ çalışmasında akupunktur, egzersiz, masaj, osteopati, meditasyon ve beslenme gibi yöntemler arasından etkili ve net bir yöntem belirlenmemiştir. Fakat bazı hastalar için bazı yöntemlerin yararlı olabileceği sonucuna ulaşılmıştır.

Yukarıdaki görüşler ve araştırma sonuçları dikkate alındığında yabancı uyruklu öğrencilerin ağrı, uyku ve yorgunlukta tamamlayıc1-alternatif tedaviler kullanım durumlarının incelenmesi gerektiğinin önemi ortaya çıkmaktadır. Kültürel farklılıkların bireylerde TAT yöntemlerinin kullanımında çeşitliliğge neden olduğu kaçınılmazdır. Hemșirelerin bireylerin kültürel farklılarına duyarlılığ arttıkça bireysel ve holistik olarak verilen hemşirelik bakımının kalitesi de artmış olacaktır. Literatürde yabancı uyruklu öğrencilerin ağr1, uyku, yorgunlukta tamamlayıc1-alternatif tedaviler kullanım durumlarının incelendiği herhangi bir çalıșma bulunmamaktadır. Bu noktadan hareketle bu çalıșmada, literatüre, hemşirelik mesleği üyelerine ve diğer sağlık çalışanlarına katkı sağlayacağ1 düşünülerek yabanc1 uyruklu öğrencilerin ağr1, uyku ve yorgunlukta tamamlayıc1-alternatif tedaviler kullanım durumlarının incelenmesi amaçlanmıştır.

\section{GEREÇ VE YÖNTEM}

Araştırma tanımlayıcı ve kesitsel tipte bir çalıșmadır. Bu araștırma 1 Mayıs -1 Temmuz 2018 tarihleri arasında, Türkiye'de bir üniversitede öğretimine devam eden uluslararası üniversite öğrencileri ile yürütülmüştür. Araştırmanın evrenini Türkiye'de bir üniversitede öğrenim gören 120 uluslararası öğrenci oluşturmaktadır. Araştırmada örnekleme yöntemine gidilmemiş planlanan tarihler arasında araştırmaya alınma kriterlerini karşılayan uluslararası öğrencilerin tümüne ulaşılması planlanmıştır. Toplamda on öğrenci anketleri eksik doldurduğu için çalıșmadan çıkarılmış, on öğrenci ise çalışmaya katılmayı istememiştir. Anketleri eksiksiz olarak yanıtlayan 100 öğrenci araştırmanın örneklemini oluşturmuştur. Bu araştırmada uluslararası öğrenciler Suriye, Afganistan ve Türkmen uyruklu öğrencilerdir.

Öğrencilerin çalışmaya alınma kriterleri; araştırmaya katılmay1 kabul eden, ilgili üniversitede lisans eğitimine devam eden, uluslararası öğrencilerden Türkçe anlama becerisine sahip olan ve iletișim problemi olmayan öğrenciler araştırmaya alınmıştır. Uluslararası öğrenciler bir y1l Türkçe dil eğitimi aldıktan sonra ilgili fakülte/yüksekokulda eğitimlerine başlamaktadırlar. Anketleri Türkçe Öğretim Merkezi'nde Türkçe dil eğitimi almış öğrenciler doldurmuştur. Çalışmaya katılan yabancı uyruklu öğrencilere, veri toplama sirasinda ve sonrasında, istedikleri zaman çalışmadan ayrılabilecekleri bilgisi verilmiştir. Bu çalışma için, Osmaniye Korkut Ata Üniversitesi Bilimsel Araştırma ve Yayın Etiği Kurulu'ndan 27/06/2018 tarihli ve 59754796050.99/ sayılı Etik Kurul Kararı alınmıştır. Ayrıca araştırmaya katılan bireylere araştırmanın amacı açıklanarak Bilgilendirilmiş Onam Formu ile sözlü ve yazılı onamları alınmıştır.

\section{Veri Araçları}

Araştırmanın verileri araştırmacılar tarafindan hazırlanan Kişisel Bilgi Formu ve Üniversite Öğrencilerinin TAT kullanımına ilişkin bilgi tutum ve davranışlarını değerlendiren form ile toplanmıştır. Araştırmacılar tarafindan literatür bilgileri doğrultusunda hazırlanan öğrencilerin sosyodemografik özellikleri (cinsiyet, yaş, kalınan yer v.s) ile ağrı yönetiminde öğrencilerin TAT kullanımına ilişkin görüşlerini içeren (ilaç kullanımı ve ilaç dışı kullandıkları yöntemler), ve kullanılan bitkisel yöntemleri belirleyen 21 soru, Uykusuzluk durumunda TAT kullanımına ilişkin görüşlerini ve kullanılan yöntemleri belirleyen 20 soru, öğrencilerin yorgunluk ile ilgili TAT’a ilişkin görüşleri ve kullanılan yöntemleri içeren 19 soruluk veri toplama formu kullanılmıştır.

Verilerin toplanmasında araştırmacılar tarafından, yüz yüze görüşme tekniği kullanılmıştır. Veri toplama yaklaşık olarak 10-15 dakikada tamamlanmıştır.

\section{İstatistiksel analiz}

Çalışmada elde edilen verilerin değerlendirme işlemi SPSS paket programında yapılmıştır. Değişkenlerin normal dağılıma uygunluk gösterdiği saptandı. Bu doğrultuda tanımlayıcı istatistiksel metotlarından 
(ortalama, frekans, yüzde ) yararlanılmıştır

\section{BULGULAR}

Çalışma sonucunun bulguları aşağıda verilen tablolarda belirtilmiştir.

Araştırmaya katılan yabancı uyruklu öğrencilerin yaş ortalamas1 21.52 'dir. Öğrencilerin $\% 43$ kadın, \%57 si ise erkek öğrencilerden oluşmaktadır. Öğrencilerin \%79'unun Suriyeli, \%15'inin Afgan, \%6'sinın Türkmen uyruklu olduğu, \%55'inin normal BKİye sahip olduğu, \%84' ünün sigara içmediği ve \%93'ünde ise kronik hastalık olmadığı belirlenmiştir (Tablo 1).

Tablo 1. Öğrencilerin sosyodemogratif özellikleri

\begin{tabular}{|l|c|c|}
\hline Değişken & \multicolumn{2}{|c|}{$21.5 \pm 2.85$} \\
\hline Yaş (ortı SD, yll) & $\mathrm{n}$ & $\%$ \\
\hline Cinsiyet & & \\
\hline Kadın & 43 & 43.00 \\
\hline Erkek & 57 & 57.00 \\
\hline Uyruk & & \\
\hline Suriyeli & 79 & 79.00 \\
\hline Türkmen & 6 & 6.00 \\
\hline Afgan & 15 & 15.00 \\
\hline Beden kitle indeksi & & \\
\hline Zayıf & 6 & 6.00 \\
\hline Normal & 55 & 55.00 \\
\hline Kilolu & 21 & 21.00 \\
\hline Obez & 18 & 18.00 \\
\hline Sigara içme & 16 & 16.00 \\
\hline $\begin{array}{l}\text { Kronik hastalık } \\
\text { varlı̆̆1 }\end{array}$ & 7 & 7.00 \\
\hline
\end{tabular}

Ağr1 yönetiminde öğrencilerin tat kullanımına ilişkin görüşleri incelendiğinde, öğrencilerin $\% 45$ 'i ağr1 gidermeye yönelik yalnızca ilaç kullanırken, \%42'si ilaçlar ve ilaç dışı yöntemleri birlikte kullandığı, \%13'ünün ise ilaç dişı yöntemler kullandığı belirlenmiştir. Ağr1 yönetiminde bitkisel yöntemlerin kullanım oranları incelendiğinde, \%22'sinin zencefil, $\% 20$ 'sinin bal, \%17'sinin bal ve zencefil karışımı, $\% 10$ 'unun aloe vera, \%8'inin sar1 kantaron, karanfil ve sarımsak, $\% 5$ 'inin sinbiyotik- probiyotikler, $\% 4$ 'ünün zerdeçal ve isırgan otu, \%2'sinin ise kekik kullandığı belirlenmiştir (Tablo 2).

Ağrı yönetiminde öğrencilerin TAT yöntemlerini bilme ve kullanım oranları incelendiğinde, $\% 54$ 'ünün masaj1, \%42'sinin sıcak-soğuk uygulamayı, \%45'inin solunum egzersizlerini, \%67'sinin hayal kurmay1, \%91'inin ise dua uygulamasını bildiği ve kullandığı belirlenmiştir. Öğrencilerin, \%53'ünün aromaterapiyi, $\% 40$ 'ının müzik terapiyi, \%69'unun ise reiki- yoga, $\% 78$ 'inin ise akupunktur ve tens uygulamasinı bilmediği ve kullanmadığı belirlenmiştir. Öğrenciler tarafından en çok bilinen ve kullanılan yöntem $\% 91$ oranla dua uygulaması, en çok bildikleri fakat kullanmadıkları yöntemin $\% 32$ oranla müzik terapi, en çok bilmedikleri ve kullanmadıkları yöntem ise $\% 78$ oranla akupunktur+ tens olarak belirlenmiştir (Tablo 3.)

Tablo 2. Ağrı yönetiminde öğrencilerin TAT kullanımına ilişkin görüşleri ve kullanılan yöntemler

\begin{tabular}{|l|l|l|}
\hline & $\mathrm{n}$ & $\%$ \\
\hline $\begin{array}{l}\text { Ağrıyı gidermeye yönelik } \\
\text { kullanılan yöntemler }\end{array}$ & & \\
\hline İlaçlar & 45 & 45.00 \\
\hline İlaç dışı yöntemler & 13 & 13.00 \\
\hline İlaçlar + İlaç dısıı yöntemler & 42 & 42.00 \\
\hline $\begin{array}{l}\text { Ağr1 yönetiminde kullanılan } \\
\text { bitkisel yöntemler }\end{array}$ & & \\
\hline Sarı Kantaron & 8 & 8.00 \\
\hline & & \\
\hline Karanfil veya sarımsak & 8 & 8.00 \\
\hline Bal & 20 & 20.00 \\
\hline Zencefil & 22 & 22.00 \\
\hline Zerdeçal & 4 & 4.00 \\
\hline Aloe vera & 10 & 10.00 \\
\hline Kekik & 2 & 2.00 \\
\hline Isırgan otu & 4 & 4.00 \\
\hline Sinbiyotik - probiyotikler & 5 & 5.00 \\
\hline Bal+zencefil & 17 & 17.00 \\
\hline
\end{tabular}

Öğrencilerin \%49’u uykusuzluğa yönelik ilaç dişı yöntemleri kullanırken, \%30’u ilaçlar ve ilaç dış1 yöntemleri birlikte kullandıkları, \%21'inin ise yalnızca ilaç kullandıkları belirlenmiştir. Uykusuzluk ile baș etmede kullanılan bitkisel yöntemler incelendiğinde $\% 24$ 'ü papatya çayı, $\% 22$ 'sinin süt ve süt ürünlerinin, \%14'ünün adaçayı ve melisa çayı, \%11'inin kediotu kökü, \%10'unun lavanta çayı, \% 5'inin ise nergis olarak belirlenmiştir (Tablo 4).

Uykusuzluk ile baş etmede öğrencilerin TAT yöntemlerini bilme ve kullanma oranları incelendiğinde, $\% 65$ 'i uyku öncesi kitap okumanın, \%67'si uyku öncesi 1lık süt, ayran, ihlamur, adaçayı, papatya çayı gibi içecekler içmenin, \%66'sı uyku öncesi tv izlemenin, \%62'si uyku öncesi llık duş almanın, \%60'ı günlük olarak egzersiz yapmanın, \%70'i çevresel uyaranları azaltmanın, \%69'u gevşeme egzersizleri ve hayal kurmanın, $\% 73$ 'ünün ise müzik terapinin etkinliğini bildikleri ve kullandıkları belirlenmiştir. 
Tablo 3. Ağrı yönetiminde öğrencilerin kullandıkları TAT yöntemleri

\begin{tabular}{|l|c|c|c|c|c|c|c|c|}
\hline & \multicolumn{2}{|c|}{ Biliyor+Kullanıyor } & \multicolumn{2}{c|}{ Biliyor+Kullanmiyor } & \multicolumn{2}{c|}{ Bilmiyor+Kullaniyor } & \multicolumn{2}{c|}{ Bilmiyor+Kullanmiyor } \\
\hline & $\mathrm{n}$ & $\%$ & $\mathrm{n}$ & $\%$ & $\mathrm{n}$ & $\%$ & $\mathrm{n}$ & $\%$ \\
\hline Masaj & 54 & 54.00 & 24 & 24.00 & 1 & 1.00 & 21 & 21.00 \\
\hline Aromaterapi & 23 & 23.00 & 23 & 23.00 & 1 & 1.00 & 53 & 53.00 \\
\hline $\begin{array}{l}\text { Sicak- soğuk } \\
\text { uygulama }\end{array}$ & 42 & 42.00 & 29 & 29.00 & 1 & 1.00 & 28 & 28.00 \\
\hline Solunum egzersizleri & 45 & 45.00 & 29 & 29.00 & 1 & 1.00 & 25 & 25.00 \\
\hline Müzik Terapi & 27 & 27.00 & 32 & 32.00 & 1 & 1.00 & 40 & 40.00 \\
\hline Hayal Kurma & 67 & 67.00 & 11 & 11.00 & 1 & 1.00 & 21 & 21.00 \\
\hline Dua Uygulamas1 & 91 & 91.00 & 3 & 3.00 & - & - & 6 & 6.00 \\
\hline Reiki+Yoga & 11 & 11.00 & 18 & 18.00 & 2 & 2.00 & 69 & 69.00 \\
\hline Akupunktur+Tens & 5 & 5.00 & 16 & 16.00 & 1 & 1.00 & 78 & 78.00 \\
\hline
\end{tabular}

Tablo 4. Uykusuzluk durumunda öğrencilerin TAT kullanımına ilişkin görüşleri ve kullanılan yöntemler

\begin{tabular}{|l|c|c|}
\hline Uykusuzluğa yönelik kullanılan yöntemler & $\mathbf{n}$ & $\mathbf{\%}$ \\
\hline İlaçlar & 21 & 21.00 \\
\hline İlaç dışı yöntemler & 49 & 49.00 \\
\hline İlaçlar + İlaç dı̧ı yöntemler & 30 & 30.00 \\
\hline Uykusuzluk durumunda kullanılan bitkisel yöntemler & & \\
\hline Papatya çayı & 24 & 24.00 \\
\hline Adaçayı & 14 & 22.00 \\
\hline Süt ve süt ürünleri & 22 & 14.00 \\
\hline Melisa Çayı & 14 & 10.00 \\
\hline Lavanta Çayı & 10 & 5.00 \\
\hline Nergis & 5 & 11.00 \\
\hline Kediotu Kökü & 11 & \\
\hline
\end{tabular}

Öğrencilerin, \%57'sinin meditasyon + hipnoz + refleksolojiyi, \%71'inin reiki + yogayı bilmediği ve kullanmadığ1 belirlenmiştir. Öğrencilerin \%73’ünün en çok bildiği ve kullandığı yöntemin müzik terapi olduğu, \%28'inin en çok bildikleri fakat kullanmadıkları yöntemin günlük egzersiz yapmak olduğu, \%71'inin ise bilmediği ve kullanmadığ1 yöntemin reiki+yoga olduğu belirlenmiştir (Tablo 5).

Tablo 5. Uykusuzluk durumunda öğrencilerin kullandıkları TAT yöntemleri

\begin{tabular}{|l|c|c|c|c|c|c|c|c|}
\hline & \multicolumn{2}{|c|}{ Biliyor+Kullanıyor } & \multicolumn{2}{c|}{ Biliyor+Kullanmıor } & \multicolumn{2}{c|}{ Bilmiyor+Kullanıor } & \multicolumn{2}{c|}{ Bilmiyor+Kullanmiyor } \\
\hline & $\mathrm{n}$ & $\%$ & $\mathrm{n}$ & $\%$ & $\mathrm{n}$ & $\%$ & $\mathrm{n}$ & $\%$ \\
\hline $\begin{array}{l}\text { Uyku öncesi kitap } \\
\text { okumak }\end{array}$ & 65 & 65.00 & 23 & 23.00 & - & - & 12 & 12.00 \\
\hline $\begin{array}{l}\text { Uyku öncesi llık süt, } \\
\text { ayran, 1hlamur, adaçayı, } \\
\text { papatya çayı gibi } \\
\text { içecekler içmek }\end{array}$ & 67 & 67.00 & 21 & 21.00 & - & - & 12 & 12.00 \\
\hline Uyku öncesi tv izlemek & 66 & 66.00 & 23 & 23.00 & - & - & 11 & 11.00 \\
\hline $\begin{array}{l}\text { Uyku öncesi llik duş } \\
\text { almak }\end{array}$ & 62 & 62.00 & 27 & 27.00 & - & - & 11 & 11.00 \\
\hline $\begin{array}{l}\text { Günlük olarak egzersiz } \\
\text { yapmak }\end{array}$ & 60 & 60.00 & 28 & 28.00 & - & - & 12 & 12.00 \\
\hline $\begin{array}{l}\text { Çevresel uyaranları } \\
\text { (șılk, ses vb) azaltmak }\end{array}$ & 70 & 70.00 & 13 & 13.00 & - & - & 17 & 17.00 \\
\hline $\begin{array}{l}\text { Gevşeme egzersizleri } \\
\text { ve hayal kurma }\end{array}$ & 69 & 69.00 & 17 & 17.00 & - & - & 14 & 14.00 \\
\hline $\begin{array}{l}\text { Meditasyon+Hipnoz+ } \\
\text { Refleksoloji }\end{array}$ & 18 & 18.00 & 24 & 24.00 & 1 & 1.00 & 57 & 57.00 \\
\hline Reiki+Yoga & 10 & 10.00 & 19 & 19.00 & - & - & 71 & 71.00 \\
\hline Müzik terapi & 73 & 73.00 & 13 & 13.00 & 1 & 1.00 & 13 & 13.00 \\
\hline
\end{tabular}


Yorgunluk durumunda öğrencilerin TAT kullanımına ilişkin görüşleri incelendiğinde, Öğrencilerin \%39’u ilaçlar ve ilaç dışı yöntemleri birlikte kullanırken, \%34’ü uykusuzluğa yönelik ilaç dışı yöntemleri kullanmakta ve \%27'si ise yalnızca ilaçları kullandıkları belirlenmiştir. Yorgunluk ile baş etmede bitkisel yöntemlerin kullanım şekilleri incelendiğinde, $\% 35$ ceviz, $\% 15$ üzüm çekirdeği, $\% 10$ ar1 poleni ve meyan kökü, \%8 sar1 kantaron, \%5 gingseng bitkisi, $\% 4$ biberiye olduğu belirlenmiştir (Tablo 6). Öğrencilerin yorgunluk ile baş etmede TAT yöntemlerini bilme ve kullanma oranları incelendiğinde, \%60'ının masaj uygulamasını, \%40'ının solunum egzersizlerini, \%50'sinin müzik terapinin etkinliğini bildiği ve kullandığ 1 belirlenmiştir. Öğrencilerin \%51'sinin hacamat, \%49'unun meditasyon+hipnozun etkinliğini bildiği fakat kullanmadığ1, \%70'inin akupuntur, \%68'inin biyoenerji, \%66'sinın reiki+yoga, \%55'inin ise aromaterapiyi bilmediği ve kullanmadığ1 belirlenmiştir. Çalışma sonucundan elde ettiğimiz bulguya göre; Öğrencilerin \%60'ının en çok masaj uygulama yöntemini bildiği ve kullandığ $1 \% 51$ 'inin ise en çok hacamat hakkında bilgi sahibi olduğu fakat kullanmadığ1, \%70'inin ise en fazla akupunkturu bilmediği ve kullanmadığı belirlenmiştir (Tablo 7).

Tablo 6. Yorgunluk durumunda öğrencilerin TAT kullanımına ilişkin görüşleri ve kullanılan bitkisel yöntemler

\begin{tabular}{|l|c|c|}
\hline Değişkenler & $\mathbf{n}$ & $\mathbf{\%}$ \\
\hline Yorgunluk durumunda kullanılan yöntemler & & 27.00 \\
\hline İlaçlar & 27 & 34.00 \\
\hline İaç dışı yöntemler & 34 & 39.00 \\
\hline İlaçlar + İlaç dışı yöntemler & 39 & \\
\hline Yorgunluk durumunda kullanılan bitkisel yöntemler & & 8.00 \\
\hline Sarı kantaron & 8 & 10.00 \\
\hline Meyan Kökü & 10 & 5.00 \\
\hline Ginseng Bitkisi & 5 & 10.00 \\
\hline Arı Poleni & 10 & 15.00 \\
\hline Üzüm Çekirdeği & 15 & 35.00 \\
\hline Ceviz & 35 & 17.00 \\
\hline Biberiye & 17 & \\
\hline
\end{tabular}

Tablo 7. Yorgunluk durumunda öğrencilerin kullandıkları TAT yöntemleri

\begin{tabular}{|l|l|l|l|l|l|l|l|l|}
\hline & \multicolumn{2}{|l|}{ Biliyor+Kullanıor } & \multicolumn{2}{l|}{ Biliyor+Kullanmiyor } & \multicolumn{2}{l|}{ Bilmiyor+Kullaniyor } & \multicolumn{2}{l|}{ Bilmiyor+Kullanmiyor } \\
\hline & $\mathrm{n}$ & $\%$ & $\mathrm{n}$ & $\%$ & $\mathrm{n}$ & $\%$ & $\mathrm{n}$ & $\%$ \\
\hline Masaj uygulamas1 & 60 & 60.00 & 24 & 24.00 & - & - & 16 & 16.00 \\
\hline Aromaterapi & 21 & 21.00 & 23 & 23.00 & 1 & 1.00 & 55 & 55.00 \\
\hline Hacamat & 19 & 19.00 & 51 & 51.00 & 1 & 1.00 & 29 & 29.00 \\
\hline Solunum egzersizleri & 40 & 40.00 & 26 & 26.00 & 1 & 1.00 & 33 & 33.00 \\
\hline Biyoenerji & 9 & 9.00 & 21 & 21.00 & 2 & 2.00 & 68 & 68.00 \\
\hline Meditasyon+Hipnoz & 12 & 12.00 & 49 & 49.00 & 1 & 1.00 & 38 & 38.00 \\
\hline Müzik tedavisi & 50 & 50.00 & 30 & 30.00 & - & - & 20 & 20.00 \\
\hline Reiki+Yoga & 6 & 6.00 & 28 & 28.00 & - & - & 66 & 66.00 \\
\hline Akupunktur & 6 & 6.00 & 24 & 24.00 & - & - & 70 & 70.00 \\
\hline
\end{tabular}

\section{TARTIŞMA}

Türkiyede eğitimine devam eden yabancı uyruklu öğrencilerin TAT kullanımına ilişkin verileri değerlendirilmiştir. Literatürde buna ilişkin çok çalışmaya rastlanmamakla beraber Doğanay ve ark'nın ${ }^{18}$ öğrenciler ile yaptıkları çalışmada, alternatif tıp kullanma yaygınlığının \%37 olduğu saptanmıştır. Uzun ve $\operatorname{Tan}^{19}$ tarafindan öğrenciler ile yapılan başka çalışmada ise, öğrencilerin $\% \quad 40.6$ 's1 TAT yöntemlerinden en az birini kullanırken, \% 20.6's1 çoklu TAT yöntemleri kullanmaktadır.

Yurt dışında öğrenciler ile yapılan çalışma da; Malezya'da, öğrencilerinin yarısından fazlası en az bir kez TAT yöntemlerini kullandıkları belirlenmiştir ${ }^{20}$. Ülkemizde ve yabancı ülkelerde öğrencilerle yapılan çalışmalar arasında farklı sonuçlar görülmesinin 
nedeni kültürel farklılıklar veya farklı TAT yöntemlerinin kullanılması olabilir.

Çalışmada, öğrencilerin \%45’i ağrıyı yönetmede ilaç kullandıkları, \%42'sinin ise, ilaç ve ilaç dışı yöntemleri birlikte kullandıkları belirlenmiştir. Özveren ve Uçar'ın yaptığı çalışmada ağrı deneyimi yaşadığını ifade eden öğrencilerin \%62.6'sı ağrilarını gidermede farmakolojik ve non-farmakolojik yöntemleri birlikte kullandıklarını belirtmiştir. Ağrıyı gidermede yalnızca farmakolojik yöntemleri kullandığını belirten öğrencilerin oran1 \%85.2'dir, farmakolojik ve nonfarmakolojik yöntemleri birlikte kullanan öğrencilerin oranı ise \%22.1 olarak belirlenmiştir ${ }^{21}$. Genel olarak ağrının giderilmesinde, farmakolojik yöntemlerin kullanılması (ağrı kesici kullanma), kolay uygulanabilir ve etkisinin hizlı olması nedeniyle bireyler tarafindan öncelikli tercih edilen yöntemdir. Öğrencilerin de ağrılarını gidermede çoğunlukla ağrı kesici kullandığını ifade etmesi bu durumu desteklemektedir. Öğrencilerin ağr1 yönetiminde non- farmakolojik yöntemleri tek başına kullanma oranlarının oldukça düşük olduğu belirlenmiştir.

Ağr1 yönetimde çok çeşitli alternatif yöntemler kullanılmasına rağmen, öğrenciler tarafindan en fazla tercih edilen bitkisel yöntemlerin; bal, zencefil, karanfil, kekik, aloe vera, 1sırgan otu olduğu, ve en çok bal ve zencefili kullandıkları belirlenmiştir. Yaşar ve Melek'in ${ }^{22}$ çalışmasında, zencefil, kekik, ısırgan otu, karanfil ve sarımsağın analjezik etkiye sahip olduğu belirtilmiştir. Ağr1 yönetiminde öğrencilerin bitkisel yöntemler dişında kullandıkları TAT yöntemleri incelendiğinde, öğrencilerin bildikleri ve en fazla kullandıkları yöntemlerin masaj, sıcak-soğuk uygulama, hayal kurma, solunum egzersizi ve dua etme yöntemleri olduğu, bu yöntemler arasinda ise en fazla kullanılan ve bilinen yöntemin ise dua etme yöntemi (\%91) olduğu belirlenmiştir. Özveren ve Uçar''n ${ }^{21}$ çalışmasında öğrenciler tarafindan ağriyı gidermede tercih edilen yöntemler incelendiğinde, sıcak uygulama ve dikkati başka yöne çekmedir. Ağrıyı gidermede kullanılan yöntemler bizim çalışma bulgularımızla benzerlik göstermektedir. Yapılan çalışmalarda da belirlendiği gibi kullanılan farmakolojik olmayan bu yöntemlerin, öğrencilerin kolaylıkla uygulayabildikleri yöntemler olduğu belirlenmiştir. Aslantaş ve Metintaş'in23 yaptıkları çalışmada, öğrencilerin baş ağrılarını gidermede ilaç almak dışında en sık kullandığı uygulamalar arasında baş ve boyuna masaj yapmak olduğu belirlenmiştir. Tercan'ın ${ }^{24}$ çalışmasında hemşirelerin sicak-soğuk uygulamaları, masaj yöntemini ve dua ile iyileşme yöntemini bildikleri ve bu uygulamalarını kullandıkları ve bu yöntemleri uyguladıkları belirlenmiştir. Aynı çalışmada \%50.3'ünün müzik tedavisini bildikleri fakat \%78.5'inin bu yöntemi uygulamadıkları belirlenmiştir. Çalışmamızda ise, ağr1 yönetiminde en fazla kullanılan ve bilinen yöntemin (\%91) dua yöntemi olduğu belirlenmiştir.

Uyku problemine karşı ögrencilerin TAT kullanımına ilişkin görüşleri incelendiğinde, \%49'unun ilaç diş1 yöntemleri, \%21'inin ise ilaç kullanımını tercih ettikleri belirlenmiştir. Araz ve ark.'nın ${ }^{25}$ yaptığ çalışmada öğrencilerin \%19.6 sının uyku problemleri nedeniyle TAT'a başvurdukları belirlenmiştir. Pearson ve arkadaşlarının ${ }^{26}$ yaptığı çalışmada, yetişkin nüfusun \%18.4'ünün son on iki ayda uyku sorunu yaşadığı, bu sorunu yaşayan bireylerin ise yaklaşık \%25'inin TAT’a başvurduğu belirlenmiştir.

Gooneratne ve arkadaşları ${ }^{27}$ tarafindan yapılan çalışmada, bireylerin uyku problemi ile baş etmek için $\% 22.1$ 'inin ise uyku ilaçlarına başvurdukları belirlenmiştir. $\mathrm{Bu}$ sonuç bulgularımızla paralellik göstermektedir. Çalışmamızda, öğrencilerin uyku probleminde en çok kullandıkları bitkisel yöntemler incelendiğinde, papatya çayı, süt ve süt ürünleri, adaçayı, melisa, kedi otu, lavanta ve nergis kullanıldığı bu bitkiler içinde de en çok tercih edilen bitkinin papatya çayı olduğu belirlenmiştir. Morelli ve arkadaşlarının $^{28}$ menopoz dönemindeki kadınlarla yaptıkları çalışmada kadınların uykusuzlukta en çok kediotu kullandıkları belirlenmiştir. Çalışma sonucumuzda da öğrencilerin \%11'inin kediotu kullandıkları görülmektedir. Baydar'ın ${ }^{29}$ yaptığ1 çalışmada kediotu, melisa ve papatya kullanımının uykusuzluğu gidermede etkili olduğu saptanmıştır. Yaşar ve Melek'in ${ }^{22}$ çalışmasında ise, Papatya çayı, Adaçayı, Süt- süt ürünleri ve Melisa Çayının uykusuzluğu gidermede etkili olduğu belirlenmiştir. Çalışma sonucumuzda bitkisel ürünlerinden en fazla $(\% 24)$ Papatya çayı ve Süt- süt ürünleri (\%22) kullanıldığı belirlenmiștir. Heasman ve Mellentin'in yaptığ1 çalışmada; insan vücudunun gündüz ve gece ritmini kontrol eden hormon olan melatoninin süt kaynaklı ürünlerde yüksek oranlarda kullanılarak uyku probleminin önüne geçilmeye çalışıldığ belirlenmiştir ${ }^{30}$. Çalışma sonucumuz yukarıdaki bulgularla örtüşmektedir.

Öğrencilerin uyku problemlerini gidermede, bitkisel yöntemler dışında kullandıkları TAT yöntemlerini bilme ve kullanma oranları incelendiğinde, uyku öncesi kitap okumanın, ılık süt, ıhlamur, adaçayı, papatya çayı gibi içecekler içmenin, uyku öncesi tv 
izlemenin, uyku öncesi llık duş almanın, günlük olarak egzersiz yapmanın, çevresel uyaranları azaltmanın, gevşeme egzersizleri, hayal kurma ve müzik terapinin etkinliğini bildikleri ve kullandıkları belirlenmiştir. $\mathrm{Bu}$ yöntemler içinde öğrencilerin en çok tercih ettikleri yöntemin Çevresel uyaranları (1ş1k, ses vb) azaltmak (\%70) olduğu belirlenmiştir. Gooneratne ve arkadaşları ${ }^{27}$ tarafindan yapılan bir çalışmada, uyku problemi yaşayan bireylerin uyku sorunuyla başetmek için \%66.4'ünün uyku öncesinde müzik dinleme ve tv izleme, \%62'sinin ise çevresel uyaranları azaltma, $\% 56.2$ 'sinin kitap okuma, \%44'ünün gündüz uyuma, \%35'inin gündüz uyumama, \%66.6'sının bitkisel ürünler veya süt içme, \%29.6'sının sıcak banyo veya masaj, \%18.6'sının yürüyüş ve egzersiz uygulamasını yaptıkları belirlenmiştir. Gooneratne ve arkadaşları nın ${ }^{27}$ çalışmasında bireylerin uyku problemlerinde \%66,4'ünün uyku öncesinde müzik dinleme, $\% 62$ 'sinin ise çevresel uyaranları azaltma yöntemini kullandıkları belirlenmiştir. Çalışmamızda benzer sonuç elde edilirken, öğrenciler tarafindan en çok tercih edilen yöntemin çevresel uyaranları (1ş1k, ses vb) azaltmak olduğu belirlenmiştir.

Yorgunluk durumunda öğrencilerin TAT kullanımına ilişkin görüşleri incelendiğinde, \%34'ünün ilaç diş1 yöntemler kullandığı, \%39'unun ise ilaç ve ilaç dış1 yöntemleri birlikte kullandıkları belirlenmiştir. Literatürde yorgunluk, tüm bireylerde sik olarak karşılaşılan ve tedavisinde oldukça güçlük yaşanan tıbbi bir yakınma olarak tanımlanmıştır ${ }^{31}$. Yorgunluk tedavisinde en çok TAT yöntemlerinin kullanıldığı saptanmıştır. Çalışmamızda öğrencilerin; \%39’unun ilaç ve ilaç dışı yöntemleri birlikte kullandığı, \%34'ünün ise ilaç dışı yöntemler kullandığı belirlenmiştir.

Yorgunluk ile baş etmede en çok kullanılan bitkisel yöntemlerin ceviz, üzüm çekirdeği, ar1 poleni, meyan kökü, sar1 kantaron, gingseng bitkisi, ve biberiye olduğu belirlenmiştir. Tercih edilen bitkisel yöntemler arasında öğrencilerin en çok (\%35) ceviz kullandığ1 belirlenmiştir. Araştırma sonucumuza benzer şekilde, Yaşar ve Melek'in ${ }^{22}$ çalışmasında, ceviz, üzüm çekirdeği, arı poleni ve gingseng bitkisinin yorgunlukta etkili olduğu belirlenmiştir. Baydar ${ }^{29}$ tarafindan yapılan çalışmada biberiye ve meyankökünün yorgunlukla başetmede etkili olduğu belirlenmiştir. $\mathrm{Bu}$ bulgular çalışma sonucumuzla örtüşmektedir.

Osbom ve arkadaşları ${ }^{32}$ tarafindan Romatoid artritli hastalarda yapılan bir çalışmada yorgunlukta biberiye kullanımının etkili olduğu belirlenmiştir. Çalışma sonucumuzda, yorgunluk durumunda kullanılan bitkisel yöntemlerden biberiye'nin de sık kullanıldığı belirlenmiş olup literatür ile uyumlu olduğu saptanmıştır.

Öğrencilerin yorgunluk ile baş etmede TAT yöntemlerini bilme ve kullanma oranları incelendiğinde öğrencilerin, masaj uygulamalarını, solunum egzersizlerini, müzik terapinin etkinliğini bildikleri ve kullandıkları belirlenmiştir. Kullandıkları bu yöntemler arasında en çok masaj (\%60) ve müzik terapisi $(\% 50)$ yöntemlerini kullandıkları belirlenmiştir. Ünal ve Akpınar'ın ${ }^{33}$ hemodiyaliz hastalarında yapmış oldukları çalışmada refleksoloji ve sırt masajının yorgunluğu azalttığı ve klinik ortamda da masajin uygulanabilir hale gelmesi gerektiği vurgulanmaktadır. Çalışma sonucumuz literatür ile desteklenmektedir. Vickers ve ve arkadaşlarının ${ }^{34}$ yaptıkları çalışmada, akupunkturun, $\% 31$ oranında yorgunluğu azalttığı saptanmıştır. Yurtkuran ve ark.'nın ${ }^{35}$ hemodiyaliz hastaları ile yaptıkları çalışmada, yoga temelli yapılan egzersizin hastaların ağrı, yorgunluk ve uykusuzluk düzeyini azalttı̆̆1 saptanmıştır. Çalışma sonucumuzda öğrencilerin \%6'sının yoga ve akupunktur yöntemleri bildikleri ve kullandıkları belirlenmiştir. Yoga ve akupunktur yöntemlerinin kullanım oranının az olması bu yöntemlerin ülkemizde henüz yeterli düzeyde bilinmediği ve tedavi sürecinde yer almadığından kaynaklandığı düşünülebilir. Çalışma sonucumuza göre, hipnoz ve meditasyonun öğrenciler tarafından bilindiği fakat, çok azının (\%12) bu yöntemi kullandığ1 belirlenmişti Untas ve arkadaşlarının ${ }^{36}$ hemodiyaliz hastalarında hipnozun etkinliğini değerlendirdikleri çalışmada, hipnozun hastaların anksiyete, depresyon, yorgunluk ve uykusuzluk semptomlarını kontrol altına almakta etkili olduğu sonucuna ulaşılmıştır. Meditasyon yöntemlerinin tedavi sürecine eklenmesi bu oranda önemli bir adım olacaktır.

Araştırma sonucunda, yabancı uyruklu öğrencilerin TAT yöntemlerini çok sık kullandıkları, en çok uykusuzluk problemi ile karşılaştıklarında, TAT yöntemlerini tercih ettikleri belirlenmiştir. Öğrencilerin ağr1 yönetiminde en çok farmakolojik yöntemlere yöneldikleri saptanmıştır.

$\mathrm{Bu}$ araştırma, bir üniversitede öğrenim gören yabanc1 uyruklu öğrenciler ile yürütülmüştür. Araştırma kesitseldir. $\mathrm{Bu}$ nedenle araştırmanın bulguları Türkiye'ye ve Türkiyede yaşayan yabancı uyruklulara genellenemez. Ayrıca kullanılan yöntemlerin süre ve 
sıklığına bakılmaması ise çalışma için sinırlılık oluşturmaktadır.

Sonuç olarak, öğrencilerin eğitim sürecinde $s 1 k$ kullanılan TAT yöntemleri konusunda, kanıta dayalı bilgiler ışığıda, temel bilgi ve becerileri kazandırabilecek düzeyde eğitimlerin verilmesi, kullanım alanı en yaygın olan uygulamaların seçilmesi ve ögrrencilere konu ile ilgili bilimsel literatüre dayalı bilgilendirmenin sağlanabilmesi önemlidir.

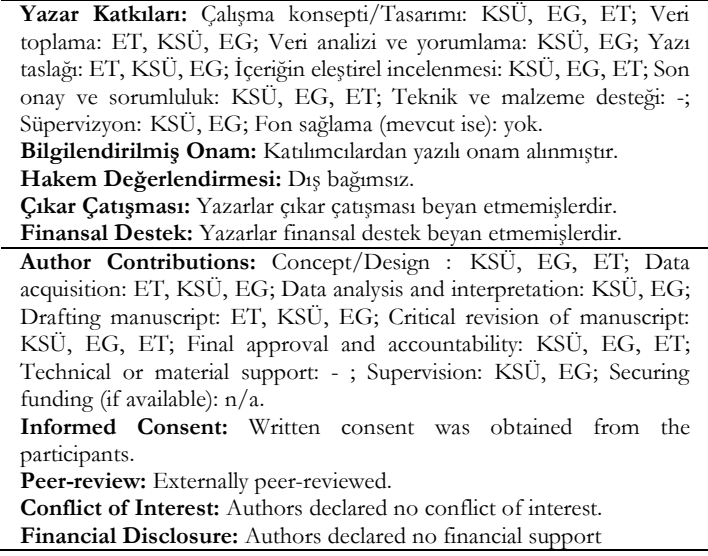

\section{KAYNAKLAR}

1. Harris PE, Cooper KL, Relton C, Thomas KJ. Prevalence of complementary and alternative medicine (CAM) use by the general population: a systematic review and update. Int J Clin Pract. 2012;10:924-39.

2. Doğan B, Karabudak AÖ, Karabacak E. Tamamlayıc1/alternatif tıp ve dermatoloji. Türkderm Deri Hastalıkları ve Frengi Arşivi Dergisi. 201246;2:62-6.

3. Bodoker G, Kronenberg FA. Public Health agenda for traditional, complementary, and alternative medicine. Am J Public Health. 2002;10:1582-91.

4. Kutlu S, Ekmekçi TÜ, Kölü A, Purisa S. Dermatoloji polikliniğine başvuran olgularda tamamlayıc1 ve alternatif tı yöntemlerinin kullanım. Turkiye Klinikleri Journal of Medical Sciences. 2009-9;6:1496502.

5. Kav S, Hanoğlu Z, Algier L. Use of complementary and alternative medicine by cancer patients in Turkey: a literature review. International Journal of Hematology and Oncology. 2008;18:32-8.

6. Taşçı S. Transcultural Nursing and complementaryalternative treatment. Türkiye Klinikleri J Public Health Nurs-Special Topics. 2015;3:34-40.

7. Tokem Y, Aytemur ZA, Yildirim Y, Fadiloglu C. Investigation into the use of complementary and alternative medicine and affecting factors in Turkish asthmatic patients. J Clin Nurs. 2012;21:698-707.
8. Leininger M. Culture care theory: a major contribution to advance transcultural nursing knowledge and practices. J Transcult Nurs. 2002;3:189-192.

9. Erdoğan Z, Atik D, Çınar S. Complementary and alternative medicine methods in chronic renal failure. Archives Medical Review Journal. 2014-23;4:773-90.

10. Yentür EA. Ağr1 ve yaşam kalitesi. 2. Sağlıkta Yaşam Kalitesi Kongresi Bildiri Kitab1. 5-7 Nisan 2007, İzmir, Meta Basım Matbacılık Hizmetleri, 2007;12-3.

11. Özveren H, Uçar H. Öğrenci hemșirelerin ağr1 kontrolünde farmakolojik olmayan bazı yöntemlere ilişkin bilgileri. Hacettepe Üniversitesi Sağlık Bilimleri Fakültesi Hemşirelik Dergisi. 2009;59-72.

12. Bayındır SK, Çürük GN. Türkiye'de ağrıya yönelik tamamlayıcı ve alternatif tıp uygulamaları konusundaki hemsirelik tezlerinin incelenmesi. Hemşirelikte Eğitim ve Araştırma Dergisi. 2015;3:162-9.

13. Yavuz M. Ağrı doğası ve kontrolü: Ağrının ilaç dışı yöntemlerle kontrolü. (Ed FE Aslan): 161-174. Ankara, Akademisyen Tip Kitabevi. 2014.

14. Banks S, Dinges DF. Behavioral and physiological consequences of sleep restriction. J Clin Sleep Med. 2007;5:519-28.

15. Can R. Sezeryan ve normal doğum yapmış kadınlarda postpartum depresyon ve yorgunluk düzeylerinin incelenmesi (Yüksek lisans tezi). Eskişehir, Osmangazi Üniversitesi, 2010.

16. Cantekin I. Sard hastalarının uyku kalitesi ve yorgunluk düzeylerinin belirlenmesi (Yüksek Llisans tezi). Erzurum, Atatürk Üniversitesi, 2009.

17. Porter NS, Jason LA, Boulton A, Bothne N, Coleman B. Alternative medical interventions used in the treatment and management of myalgic encephalomyelitis/chronic fatigue syndrome and fibromyalgia. J Altern Complement Med. 2010;3:23549.

18. Doğanay S, Guzel D, Öztürk D, Tanyeli A. Complementary and alternative medicine: understanding, attitude and usage among Turkish health sciences and medical students. Journal of Contemporary Medicine. 2018;1:48-54.

19. Uzun O, Tan M. Nursing students' opinions and knowledge about complementary and alternative medicine therapies. Complement Nurs Midwifery. 2004;10:239-44.

20. Hasan SS, Yong CS, Babar MG, Naing CM, Hameed A, Baig MR et al. Understanding, perceptions and selfuse of complementary and alternative medicine (CAM) among Malaysian pharmacy students. BMC Complement Altern Med. 2011;11:95.

21. Özveren $\mathrm{H}, \mathrm{Uçar} H$. The knowledge of student nurses on some non-pharmacological methods used in the pain control. Hacettepe University Faculty of Health Sciences Nursing Journal. 2009;59-72.

22. Yaşar H. Melek S. Beslenme ve Besinler. Ankara, Hatiboğlu Yayınevi, 2014.

23. Aslantaş D, Metintaş S, Ünsal A, Kalyoncu C. Eskișehir kırsal kesim öğrencilerinde baș ağrısı sıklı̆̆1 
ve etkileyen etmenler. Sürekli Tip Eğitimi Dergisi. 2007;1:1-5.

24. Tercan B. Hemşirelerin ağr1 yönetiminde ilaç dışı yöntemleri bilme ve uygulama durumları (Yüksek Lisans Tezi). Malatya, İnönü Üniversitesi, 2015.

25. Araz NÇ, Taşdemir HS, Kılıç SP. Sağlık bilimleri fakültesi öğrencilerinin tıp dışı alternatif ve geleneksel uygulamalar konusundaki görüşlerinin değerlendirilmesi. Gümüşhane Üniversitesi Sağllk Bilimleri Dergisi. 2012;1:4.

26. Pearson NJ, Johnson L, Nahin R. Insomnia, trouble sleeping, and complementary and alternative medicine. Arch Intern Med. 2006; 166:1775*82.

27. Gooneratne NS, Tavaria A, Patel N, Mashusudan L, Nadaraja D, Onen F et al. Perceived effectiveness of diverse sleep treatments in older adults. J Am Ger Soc. 2011:59:297-303.

28. Morelli V, Naquin C. Alternative therapies for traditional disease states: menopause. Am Fam Physician. 2002;1:129-135.

29. Baydar H. Tibbi ve aromatik bitkiler bilimi ve teknolojisi. SDÜ Ziraat Fakültesi. 2009;51:122-3.

30. Heasman M, Mellentin J. New Nu Vim prepares to be swallowed up. NNB. 2002;8:29-30.
31. Sayın A, Candansayar S. Yorgunluk kavramı ve yorgun hastalara klinik yaklaşım. Gazi Tip Dergisi. 2007;1:18 .

32. Osborn C, Barlas P, Baxter G, Barlow J. Aromatherapy: a survey of current practice in the management of rheumatic disease symptoms. Complement Ther Med. 2001;2:62-7.

33. Unal KS, Akpinar RB. The effect of foot reflexology and back massage on hemodialysis patients' fatigue and sleep quality. Complement Ther Clin Pract. 2016;24:139-44.

34. Vickers AJ. Statistical reanalysis of four recent randomized trials of acupuncture for pain using analysis of covariance. Clin J Pain. 2004;20:319-23.

35. Yurtkuran M, Alp A, Yurtkuran M, Dilek KA. Modified yoga-based exercise program in hemodialysis patients: a randomized controlled study. Complement Ther Med. 2007;3:164-71.

36. Untas A, Chauveau P, Dupré-Goudable C, Kolko A, Lakdja $\mathrm{F}$ et al. The effects of hypnosis on anxiety, depression, fatigue, and sleepiness in people undergoinghemodialysis: a clinical report. Int J Clin Exp Hypn. 2013;4:475-83. 